\title{
染料敏化太阳能电池过渡金属化合物对电极制备方法研究进展
}

\author{
张陈乐 ${ }^{1,2}$, 张培新 ${ }^{1,2}$, 云斯宁 ${ }^{1}$, 李永亮 ${ }^{2}$, 何挺树 ${ }^{1}$
}

(1. 西安建筑科技大学 材料与矿资学院, 西安 710055; 2. 深圳大学 化学与化工学院, 深圳 518060)

摘 要: 染料敏化太阳能电池(dye-sensitized solar cells, DSSCs)作为制作工艺简易, 成本低廉, 环境友好的新型太阳 能电池, 其发展一直备受关注。对电极作为 DSSC 的核心部件之一, 其制备工艺会直接影响到 DSSC 的发展和应用。 以低成本高性能的催化材料代替传统的贵金属 Pt 对电极是降低 DSSC 生产成本的有效途径之一。具有类 Pt 催化性 能的过渡金属化合物(TMCs) 由于种类繁多, 制备方式简单多样, 近年来成为 DSSC 对电极研究中的热点。本文综述 了 DSSC 过渡金属化合物对电极的最新研究进展，总结概括了过渡金属化合物对电极的制备方法以及性能特点，并 对其发展方向和应用前景进行了分析。

关 键 词: 染料敏化太阳能电池; 对电极; 过渡金属化合物; 制备方法; 综述

中图分类号: TK513 文献标识码: A

\section{Recent Progress on Preparation of Transition Metal Compounds as Counter Electrodes for Dye-sensitized Solar Cells}

\begin{abstract}
ZHANG Chen-Le ${ }^{1,2}$, ZHANG Pei-Xin $^{1,2}$, YUN Si-Ning ${ }^{1}$, LI Yong-Liang ${ }^{2}$, HE Ting-Shu $^{1}$
(1. School of Materials \& Mineral Resources, Xi' an University of Architecture and Technology, Xi'an 710055, China; 2. School of Chemistry and Chemical Engineering, Shenzhen University, Shenzhen 518060, China)

Abstract: Dye-sensitized solar cells (DSSCs) have attracted extensive attention in recent years due to their simple fabrication, low cost and environmental friendliness. The production process for counter electrode (CE) as one of the key components of DSSC, will significantly affect the DSSCs development and application. Therefore, it is important to develop low cost and high performance catalytic materials instead of noble metal Pt to reduce the production cost of DSSC. Transition metal compounds with Pt-like catalytic activity have become a hot research area for CEs of DSSC in recent years, due to their wide variety and simple preparation. This review briefly addresses recent progresses of transition metal compound CEs of DSSC, focusing on their preparation methods and performance. In addition, the development trends and application prospects of CEs were also discussed.
\end{abstract}

Key words: dye-sensitized solar cells; counter electrode; transition metal compound; preparation method; review

染料敏化太阳能电池(dye-sensitized solar cells, DSSC) 以其成本低廉、封装简单、环境友好等优势, 自 1991 年以来得到了长足的发展 ${ }^{[1-3]}$ 。目前实验室 条件下 DSSC 的光电转换效率最高已达到 $13 \%{ }^{[4]}$ 。
因此, DSSC 被认为是最有希望取代硅晶类太阳能 电池的新型太阳能电池。但是 DSSC 要实现产业应 用, 急需提高电池光电转换效率, 以及进一步降低 成本。

收稿日期：2015-06-16；收到修改稿日期：2015-09-06

基金项目: 国家自然科学基金(51374146); 深圳市基础研究计划项目(JCYJ20140418095735619)

National Natural Science Foundation of China (51374146); Shenzhen Government's Plan of Science and Technology Research Project (JCYJ20140418095735619)

作者简介: 张陈乐(1988-), 女，博士研究生. E-mail: 87611.320@163.com

通讯作者: 张培新, 教授. E-mail: pxzhang@szu.edu.cn 
传统的 DSSC 主要由三部分组成: 染料敏化的 光阳极、对电极(counter electrode, $\mathrm{CE}$ ) 以及填充在光 阳极与对电极之间的电解质。其中 $\mathrm{CE}$ 一般由导电 祄底和催化材料组成, 在 DSSC 中的主要作用: 一 是依靠导电祄底收集工作电极由外回路传来的电子; 二是利用催化材料将电解质中得到电子的电子受体 催化还原再生, 进而确保染料还原再生。Hauch 等 ${ }^{[5]}$ 就认为 $\mathrm{I}^{-} / \mathrm{I}_{3}{ }^{-}$电解质在 $\mathrm{Pt}$ 对电极的催化反应机理分为 4 步:
(1) $\mathrm{I}^{-}+\mathrm{Pt} \leftrightarrow \mathrm{I}^{-}(\mathrm{Pt})$
( $\mathrm{I}^{-}$吸附在 $\mathrm{Pt}$ 上) 快
(2) $\mathrm{I}^{-}(\mathrm{Pt}) \leftrightarrow \mathrm{I}(\mathrm{Pt})+\mathrm{e}^{-}$
(I' 被氧化)
(3) $\mathrm{I}(\mathrm{Pt})+\mathrm{I}(\mathrm{Pt}) \leftrightarrow \mathrm{I}_{2}+2 \mathrm{Pt}$
( $\mathrm{I}_{2}$ 的还原)
(4) $\mathrm{I}^{-}+\mathrm{I}_{2} \leftrightarrow \mathrm{I}_{3}{ }^{-}$
$\left(\mathrm{I}_{3}^{-}\right.$的还原)
慢
快

其中过程(2)为慢反应是催化反应的决速过程。因此, 理想的对电极材料应该具有良好的导电性能、较高 的比表面积、较低的表面电阻、良好的稳定性以及 高催化活性。

Pt 沉积在掺氟的氧化锡导电玻璃(FTO)上制备的 传统 Pt 对电极, 由于具有良好的催化活性、导电性和 稳定性, 因此, 在 DSSC 中表现出良好的性能 ${ }^{[6-7]}$ 。但 是, $\mathrm{Pt}$ 容易与 $\mathrm{I}^{-} / \mathrm{I}_{3}{ }^{-}$电解质发生反应被腐蚀, 此外, $\mathrm{Pt}$ 价格昂贵、资源稀缺也在很大程度上限制了 DSSC 的生产应用 ${ }^{[8]}$ 。因此, 不断有学者希望研发出成本低 廉、催化性能优异的无 Pt 对电极材料。目前国内外 对 DSSC 无 Pt 对电极的研究主要集中在碳材料 ${ }^{[9-11]}$ 、 导电聚合物 ${ }^{[12-15]}$ 和金属化合物等方面。碳对电极具 有耐腐蚀, 成本低以及高催化活性等优势, 但碳材 料与祄底结合力差, 电极不透明等因素也制约着其 大规模应用。导电聚合物电极突出的优势在于透明 且可应用于柔性祄底, 但就目前而言其耐用性有待 提高。目前, 与 $\mathrm{Pt}$ 有相似的电子结构和催化性能, 但制备方式多样、制作成本低廉、性能稳定的过渡 金属化合物 (TMCs) 对电极发展最为迅速 ${ }^{[16-17]}$ 。本文 将主要就 TMCs 对电极的制备方法以及结构性能进 行分析比较。

\section{1 模板法}

软模板法是在过渡金属前驱体中添加软模板作 为造孔剂, 并嵌入碳材料, 最后在流动 $\mathrm{N}_{2}$ 环境下进 行烧结处理。

$\mathrm{Wu}$ 等制备的 $\mathrm{VC}-\mathrm{MC}^{[18]}$ 和 $\mathrm{WO}_{2}-\mathrm{MC}^{[19]}$ 电极, 其 $\mathrm{PCE}$ 分别为 $7.63 \%$ 和 $7.76 \%$, 高于 $\mathrm{Pt}$ 对电极电池的 效率 $\left(7.50 \%\right.$ 和 $7.55 \%$ )。 Yun 等合成的 $\mathrm{TaO}-\mathrm{MC}^{[20]}$ 以 及 $\mathrm{HfO}_{2}-\mathrm{MC}^{[21]}$ 均表现出良好的催化活性。其电池的
PCE 分别达到 $8.09 \%$ 和 $7.75 \%$, 是同条件下 Pt 对电 极的 1.11 倍和 1.08 倍。Lee 等 ${ }^{[22]}$ 制备的 TiN-C 电极 性能优异, 在 $\mathrm{T}^{-} / \mathrm{T}_{2}$ 电解质条件下其电池的 $\mathrm{PCE}$ (6.71\%)是 Pt 对电极的 2.02 倍(图 1)。

软模板的加入在结构中形成的大量孔洞有利于 电解质的流动, 也为催化还原提供了大量的活性位 点。此外, 该制备方式可以很容易地扩展到其他 TMCs-MC 复合材料的合成, 进一步用于不同的催 化剂领域, 如燃料电池催化剂、生物传感器等。

\section{2 物理化学法}

\section{1 “尿素-金属” 路线法}

“尿素一金属” 路线法又称为 “一锅法”, 是目 前制备 TMCs 对电极的主要方法之一。通过在各种 过渡金属水合盐前驱体中加入尿素，烧结后产物 以刮涂或者喷涂的方式转移到祄底上制成对电极 (图 2) ${ }^{[23]}$ 。该方法只需改变反应物的摩尔比或者烧 结温度就能改变产物晶型, 将过渡金属氧化物转变 为氮化物或者碳化物 ${ }^{[24-26]}$ 。

Yun 等 ${ }^{[27-29]}$ 以该法合成了 $\mathrm{TaO}_{x} 、 \mathrm{Ta}_{2} \mathrm{O}_{5} 、 \mathrm{TaO}$ 以 及 $\mathrm{HfO}_{2}$ - $\mathrm{C}$ 等对电极, 其 DSSC 的 PCE 分别达到 $6.79 \% 、 4.08 \% 、 6.48 \%$ 和 $6.71 \%$, 对应的 $\mathrm{Pt}$ 对电极

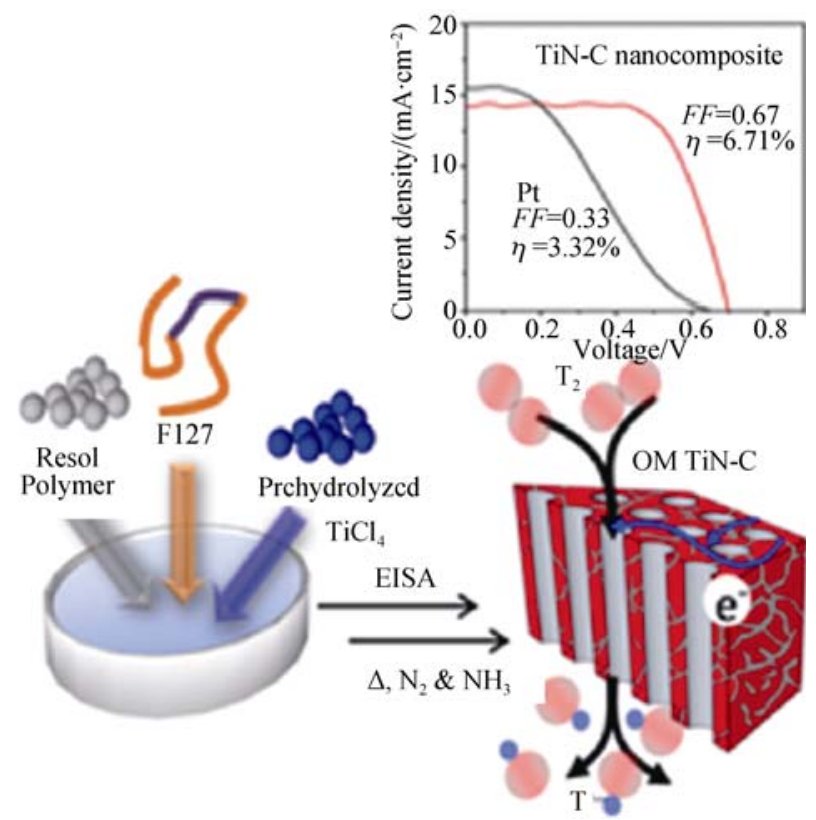

图 1 使用 F127 软模板合成有序介孔材料 TiN-C 的示意图, 内嵌图为 Pt/FTO 和 TiN-C/FTO 为对电极 DSC 的电流-电压特 性曲线 ${ }^{[22]}$

Fig. 1 Schematic for the synthesis of ordered mesoporous TiN-C nanocomposites, photocurrent-voltage curves of DSCs employing the Pt/FTO, and TiN-C/FTO counter electrodes (insets) $^{[22]}$ 
的 PCE 分别是 $7.57 \% 、 7.16 \% 、 7.16 \%$ 和 $7.19 \%$ 。 Wu 等 ${ }^{[18]}$ 制备了过渡金属 $\mathrm{W} 、 \mathrm{Mo} 、 \mathrm{Nb} 、 \mathrm{Cr} 、 \mathrm{Zr} 、 \mathrm{Ti}$ 和 $\mathrm{V}$ 等氧化物、氮化物及碳化物。通过调节 $\mathrm{N}_{2}$ 处理温 度得到 $\mathrm{N}$ 掺杂过渡金属碳化物(图 3), 其中 $\mathrm{TiC}(\mathrm{N})$ 、 $\mathrm{VC}(\mathrm{N})$ 和 $\mathrm{NbC}(\mathrm{N})$ 均表现出比相应的碳化物更好的 催化活性。 $\mathrm{Wu}$ 等 ${ }^{[30]}$ 还制备了 $\mathrm{Mo}_{2} \mathrm{~N} / \mathrm{Ti}$ 和 $\mathrm{W}_{2} \mathrm{~N} / \mathrm{Ti}$ 对电极, 其电池的 PCE 分别达到 Pt 对电极的 91\% 和 $83 \%$ 。

“尿素-金属” 路线法对于制备过渡金属氮化物 或者碳化物无疑是一种简单有效的技术。但是其合 成产物纯度低、易团聚、比表面积低、导电性差、 稳定性差, 严重影响着对电极的性能。

\section{2 纳米油墨技术}

纳米油墨技术，即将前驱体分散液通过喷雾、 印刷或者纺丝在祄底表面, 最后通过退火获得单分 散的纳米颗粒。

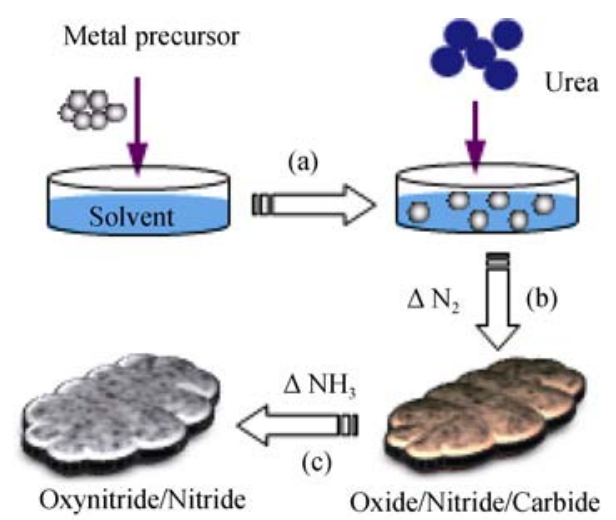

图 2 使用“尿素-金属”路线化学合成 TMCs 的示意图 ${ }^{[23]}$

Fig. 2 Schematic illustration for the chemical synthesis of TMCs by using a urea-metal route ${ }^{[23]}$
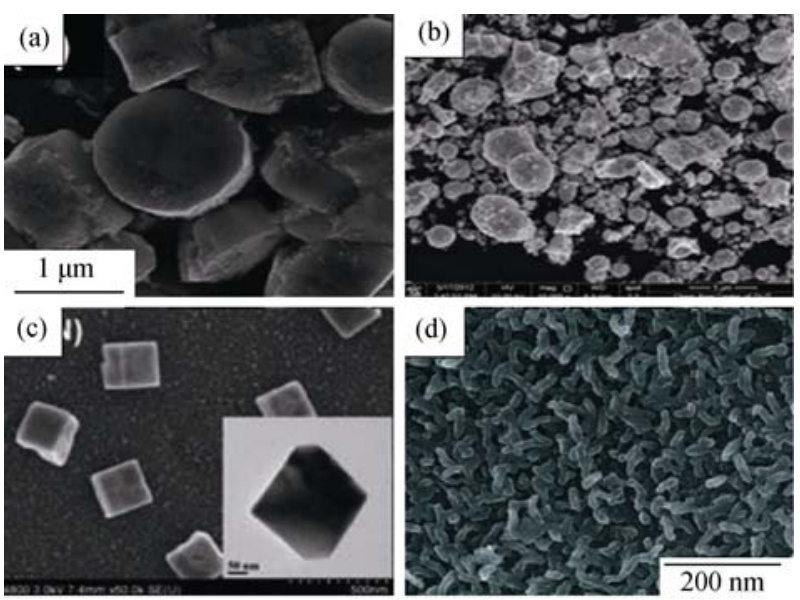

图 $3(\mathrm{a} \sim \mathrm{d})$ 分别为 $\mathrm{TaO}_{\mathrm{X}}{ }^{[27]} 、 \mathrm{Ta}_{2} \mathrm{O}_{5}^{[28]} 、 \mathrm{VC}(\mathrm{N})^{[18]}$ 和 $\mathrm{VN}^{[26]}$ 的 SEM 照片, 内嵌图为对应样品的 TEM 照片

Fig. 3 (a-d) SEM and TEM images (inset of c) of the $\mathrm{TaO}_{\mathrm{X}}{ }^{[27]}$, $\mathrm{Ta}_{2} \mathrm{O}_{5}{ }^{[28]}, \mathrm{VC}(\mathrm{N})^{[18]}$ and $\mathrm{VN}^{[26]}$
Chen 等 ${ }^{[31]}$ 以纳米晶 $\mathrm{FeS}_{2}$ 墨水制备了半透明 $\mathrm{CE}$ 。使用 $\mathrm{FeS}_{2} / \mathrm{ITO} / \mathrm{PEN}$ 对电极的 DSSC 效率为 $7.31 \%$ ，接近 Pt 对电极的 $\operatorname{PCE}(7.52 \%)$ 。Tuan 等 ${ }^{[32]}$ 制备的 $\mathrm{Co}_{9} \mathrm{~S}_{8} / \mathrm{FTO}$ 对电极电池 $\mathrm{PCE}$ 为 $7.00 \%$, $\mathrm{Co}_{9} \mathrm{~S}_{8} / \mathrm{Mo}$ 的 $\mathrm{PCE}$ 为 $6.91 \%$, 均接近 $\mathrm{Pt}$ 对电极的 $\mathrm{PCE}(7.13 \%)$ 。金属硫化物( $\mathrm{MS}, \mathrm{M}=\mathrm{Ni}, \mathrm{Co})$ 纳米粒子 (NPs)/石墨烯的复合薄膜对电极(图 4) ${ }^{[33]}$, 其 DSSC 的 PCE 分别为 $5.25 \%(\mathrm{NiS} /$ 石墨烯)和 $5.04 \%(\mathrm{CoS} /$ 石 墨烯), 光电性能均优于同条件下 $\mathrm{Pt} / \mathrm{FTO}(5.00 \%)$ 对 电极。

此外，纳米油墨技术还可应用于制备过渡金属 氧化物、硒化物等。另外, 前驱体分散液可以根据 需要喷涂在不同类型的祄底上。简便的喷印工艺、 低廉的成本以及优异的电催化活性，使得纳米油墨 技术有望应用于工业化生产大面积的 DSSC。

\section{3 气相沉积法}

2010 年, Xia 等 ${ }^{[34]}$ 通过气相沉积 $\mathrm{V}_{2} \mathrm{O}_{5}$ 与 $\mathrm{Al}$ 片 复合应用于固态 DSSC 对电极(图 5)。 $\mathrm{V}_{2} \mathrm{O}_{5} / \mathrm{Al}$ 对电 极 DSSC 的 PCE 达到相同条件下 $\mathrm{Ag}$ 对电极的 77\%。 除了性能媲美贵金属银电极，这种新型电极可以广 泛应用于其他固体电池电极。为替换金银等贵金属 电极提供了一种方法, 可以大幅度降低固体 DSSC 的成本。

气相沉积法操作简单，反应灵活可控，但其沉 积速率低，工作温度高，反应剩余气体有毒，易腐 蚀仪器。此外, 该技术难以应用于局部成膜, 对于电 池电极的制备有着较大的局限性 ${ }^{[35-36]}$ 。

\section{4 电沉积法}

由于大多数的过渡金属都可以在溶液中电解发 生氧化还原反应，因此电沉积法在制备过渡金属化 合物上有着最为广泛的应用 ${ }^{[37-40]}$ 。

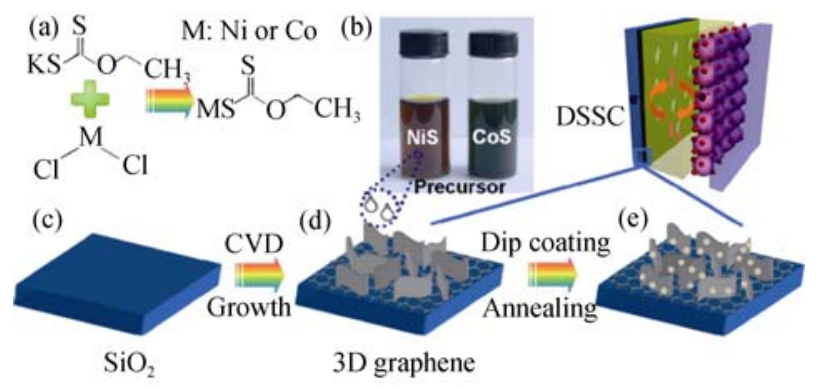

图 $4 \mathrm{MS}$ /石墨烯对电极的制备流程 ${ }^{[33]}$

Fig. 4 Overall procedure for the fabrication of MS/graphene composite CEs for DSSCs:

(a) Reaction equation of MS precursor preparation; (b) Well dispersed MS precursor solutions in acetone and ethanol solvents; (c) Dielectric $\mathrm{SiO}_{2}$ substrate; (d) Graphene film directly grown on $\mathrm{SiO}_{2}$ substrate; (e) MS NPs loaded on the graphene surface; (f) Application of $\mathrm{MS} /$ graphene composite CEs in DSSCs ${ }^{[33]}$ 


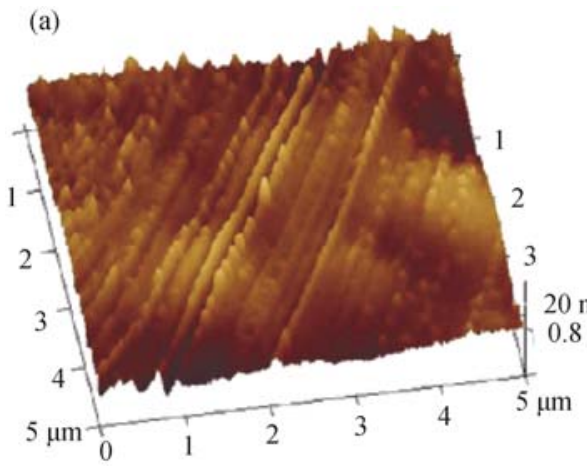

(b)

图 $5(\mathrm{a}, \mathrm{b})$ 气相沉积在固体 DSSC 空穴传输层的 $10 \mathrm{~nm}$ 厚 $\mathrm{V}_{2} \mathrm{O}_{5}$ 的 AFM 图 ${ }^{[34]}$

Fig. 5 (a-b) AFM images of $10 \mathrm{~nm} \mathrm{~V}_{2} \mathrm{O}_{5}$ deposited on Spiro-OMeTAD at $0.05 \mathrm{~nm} \cdot \mathrm{s}^{[34]}$

Wang 等 ${ }^{[41]}$ 制备的 $\mathrm{CoS} / \mathrm{ITO} / \mathrm{PEN}$ 对电极, 在 $60^{\circ} \mathrm{C}$ 环境下, 长时间 $(1000 \mathrm{~h})$ 光照其电池的 PCE 依 然可以达到初始值的 $85 \%$, 显示出优异的稳定性。 另一方面, 对电极以 $\mathrm{Co}$ 作为原料, DSSC 的成本比 使用 $\mathrm{Pt}$ 低近百倍。 $\mathrm{Wu}$ 等 ${ }^{[42]}$ 利用电沉积法制备了 $\mathrm{Ni}_{5} \mathrm{P}_{4}$ 介孔粒子对电极, 其电池的 PCE 为 $7.60 \%$, 高 于相同条件下 $\mathrm{Pt}$ 对电极的 $\operatorname{PCE}(7.20 \%)$ 。此外, $\mathrm{Ni}_{5} \mathrm{P}_{4} / \mathrm{FTO}$ 电极表现出较高的透明度, 使得该材料 还可以应用于背照式 DSSC。Zhang 等 ${ }^{[43]}$ 将具有类 似石墨烯结构的 CoSe 膜(图 6)作为 DSSC 对电极, 在 CoSe 电极界面上呈现出与 $\mathrm{Pt}$ 电极相比更低的传 输电阻, 其电池的 PCE 最高达到 $7.30 \%$, 高于相同 条件下 Pt 对电极 $(6.91 \%)$ 的 DSSC 效率。
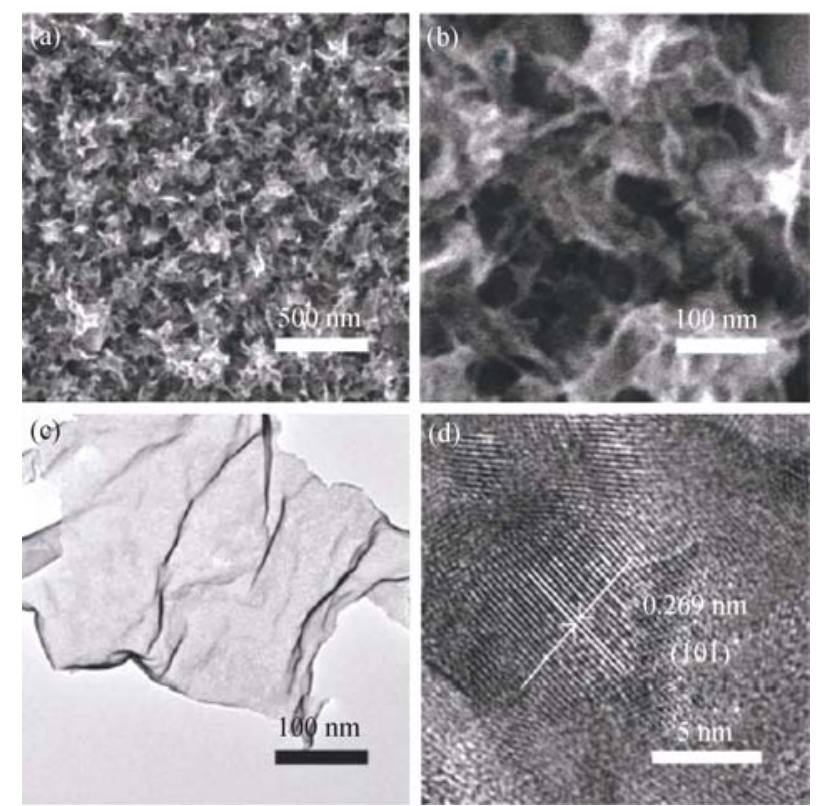

图 $6(\mathrm{a}, \mathrm{b})$ 在 $\mathrm{pH}=3.5$ 条件下制备的 CoSe 电极的 SEM 照片, (c) 电沉积形成的 CoSe 薄膜的 TEM 照片和 (d)由 HTEM 显示的 $\mathrm{CoSe}$ 在(101)的晶格间距大小 ${ }^{[43]}$

Fig. 6 (a-b) Typical SEM images of cobalt selenide electrode prepared at $\mathrm{pH}=3.5$, (c) typical TEM image of the cobalt selenide layers peeled from the electrodeposited films, and (d) HTEM showing (101) lattice fringes of $(c)^{[43]}$
电沉积技术制备 TMCs 对电极，由于生产工艺 简单、成本低廉、生产周期短和电极性能优异，无 疑将极大地推动 DSSC 工业化生产进程。

\section{5 原位生长技术}

原位生长技术不仅生产方式简易，制备结构、 形貌多样, 祄底选择多样化, 而且无需后处理即可 应用于 DSSC 对电极 ${ }^{[44-46]}$ 。

Zhao 等 ${ }^{[47}$ 原位生长的 $\mathrm{NiS} / \mathrm{FTO}$ 对电极的性能 优越, PCE 达到 $7.41 \%$, 接近 Pt 对电极的 $\mathrm{PCE}$ $(7.55 \%)$ 。 $\mathrm{KIM}$ 等 ${ }^{[48]}$ 制备了 $\mathrm{CoS}_{2} 、 \mathrm{NiS}$ 和不同 $\mathrm{Ni}$ 含 量掺杂 $\mathrm{CoS}_{2}$ 等对电极, 测试其性能时发现，15\%的 $\mathrm{Ni}$ 掺杂 $\mathrm{CoS}_{2}$ 对电极电池的 PCE 最高, 达到 5.50\%, 而 Pt 对电极的 PCE 只有 $5.21 \%$ ，未掺杂的 $\mathrm{CoS}_{2}$ 对 电极的 PCE $(4.01 \%)$ 最低, 说明掺杂能有效地改善结 构性能。Wang 等 ${ }^{[49-50]}$ 原位制备的各电极中, 石墨烯 状 $\mathrm{Co}_{0.85} \mathrm{Se} / \mathrm{FTO}$ 对电极 $(9.40 \%)$ 与 $\mathrm{Pt}$ 对电极 $(8.64 \%)$ 相 比具有更高的转换效率。用 $\mathrm{NiSe}_{2} / \mathrm{FTO}$ 电极制备的 电池 PCE 高达 $8.69 \%$, 是相同条件 Pt 对电极 PCE 的 1.08 倍(图 7)。

综上所述，原位生长技术制备的结构多为单一 晶型, 有利于电子传输; 同时结构表面积大, 催化 活性位点多。说明原位生长是一种制备成本低廉, 高催化活性的 DSSC 对电极材料的有效方法。

\section{6 溶剂热法/水热法}

相比原位生长技术，溶剂热制备的 TMCs 及其 复合电极种类更多, 结构形貌更为多样 ${ }^{[1-53]}$ 。此外, 在制备过程中只需简单的改变反应条件即可得到不 同形貌的产物 ${ }^{[54-57]}$ 。

Dou 等 ${ }^{[58]}$ 比较了 $\mathrm{Ni}_{12} \mathrm{P}_{5} / \mathrm{FTO}$ 与 $\mathrm{Ni}_{12} \mathrm{P}_{5} /$ 石墨烯电 极电池的性能差异, 发现, $\mathrm{Ni}_{12} \mathrm{P}_{5}$ 中添加石墨烯成功 地提高了电池性能, $\mathrm{PCE}$ 由纯 $\mathrm{Ni}_{12} \mathrm{P}_{5}$ 的仅 $3.94 \%$ 提高 到 $5.70 \%$, 接近 $\mathrm{Pt}$ 对电极的 $\mathrm{PCE}(6.08 \%)$ 。Guo 等 ${ }^{[59]}$ 以复合氢氧化物介导法 $(\mathrm{CHM})$ 合成了 $\mathrm{CoTe}$ 和 $\mathrm{NiTe}_{2}$ 

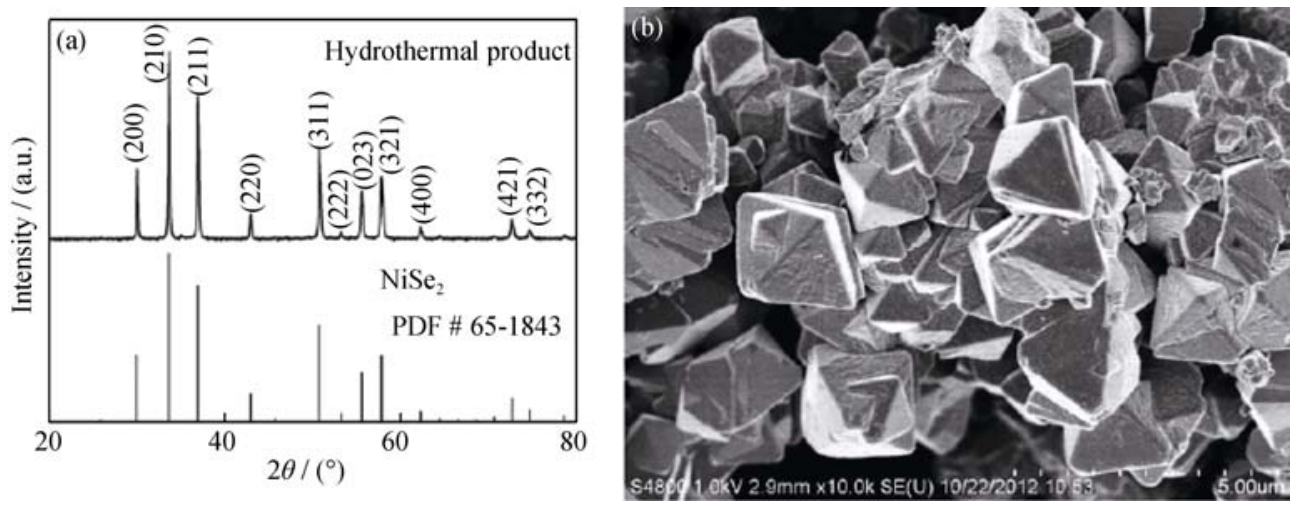

图 7 (a)原位生长技术所制备样品的 XRD 图谱以及与其相符的(PDF\#65-1843)标准 XRD 图谱, (b)原位生长技术制备的 $\mathrm{NiSe}_{2}$ 纳米颗粒 SEM 照片 ${ }^{[50]}$

Fig. 7 (a) XRD patterns and the corresponding simulated XRD data for $\mathrm{NiSe}_{2}$ (PDF \#65-1843), and (b) typical SEM image of the $\mathrm{NiSe}_{2}$ particles $^{[50]}$

纳米结构。此制备方式不需要添加有机分散剂以及密 封处理, 有利于应用于大规模生产。更重要的是, 以 $\mathrm{CoTe}$ 和 $\mathrm{NiTe}_{2}$ 为对电极的 DSSC 呈现出高达 $6.92 \%$ 和 $7.21 \%$ 的光电转换效率, 媲美相同条件下 Pt 对电 极电池的 PCE(7.04\%)(图 8)。该研究的发现无疑扩大 了过渡金属碲化物的应用范围, 另一方面也为发展低
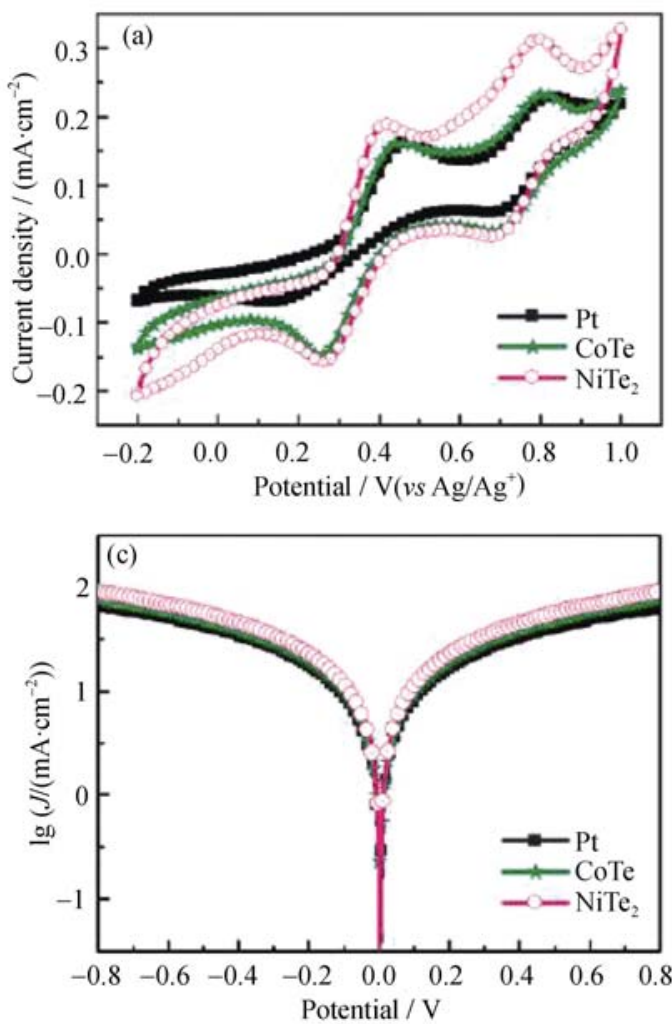

成本、高效率的 DSSC 对电极提供了新思路。

\section{7 静电纺丝技术}

该方法作为一种新型的纳米材料制备技术，通 过改变其加工参数, 可以获得不同类型的纳米纤 维。但是，截至目前静电纺丝技术应用于制备 TMCs 对电极的报道较少。
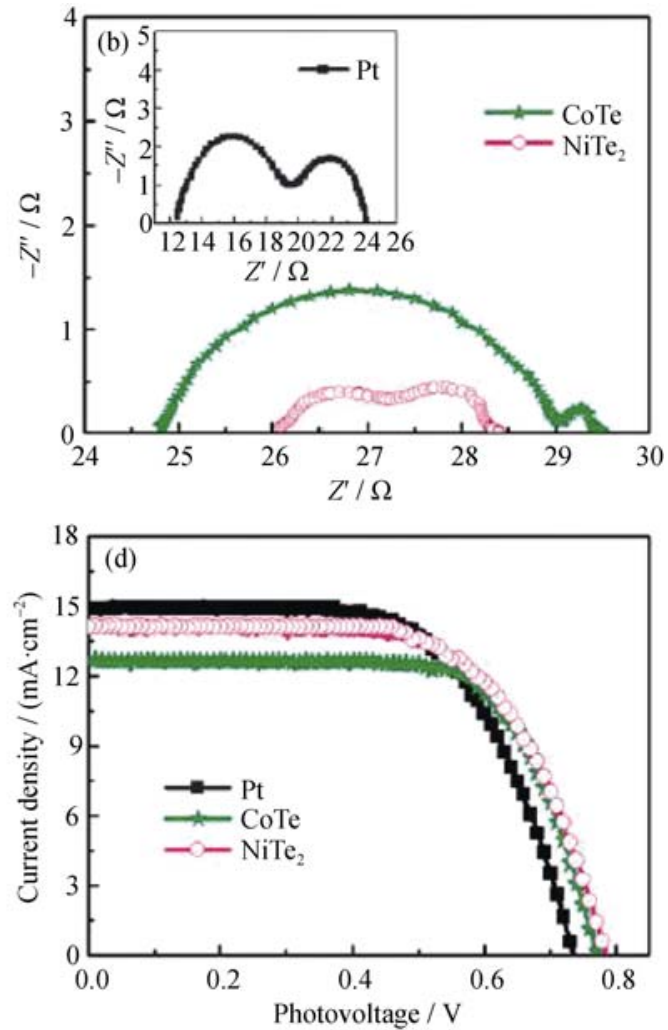

图 8 (a) 以 $\mathrm{I}^{-} / \mathrm{I}_{3}{ }^{-}$为电解质 $\mathrm{CoTe} 、 \mathrm{NiTe}_{2}$ 和 $\mathrm{Pt}$ 对电极的电池 $C-V$ 曲线, (b) $\mathrm{CoTe} 、 \mathrm{NiTe}_{2}$ 和 $\mathrm{Pt}$ 对电极的对称薄层电池的 EIS 图, (c) $\mathrm{CoTe} 、 \mathrm{NiTe}_{2}$ 和 $\mathrm{Pt}$ 对电极的对称薄层电池的塔菲尔极化曲线, (d) CoTe、 $\mathrm{NiTe}_{2}$ 和 $\mathrm{Pt}$ 对电极的染料敏化太阳能电池的 $J-V$ 曲线 ${ }^{[59]}$ Fig. 8 (a) Cyclic voltammograms of the triiodide/iodide redox couple for CoTe, $\mathrm{NiTe}_{2}$ and Pt CEs, (b) nyquist plots of EIS for the symmetrical cells, (c) tafel polarization curves of the symmetrical cells, and (d) $J$ - $V$ curves of the DSCs based on CoTe, NiTe 2 , and Pt CEs ${ }^{[59]}$ 
Zhao 等 ${ }^{[60]}$ 将制备的 $\mathrm{TiC} / \mathrm{C}$ 纳米纤维浸泡于 $\mathrm{H}_{2} \mathrm{PtCl}_{6}$ 溶液中, 添加还原剂, 最终获得表面修饰着 大量铂纳米粒子 (Pt NPs)的 $\mathrm{TiC} / \mathrm{C}$ 纳米纤维(图 9)。 电化学测量表明, TiC-C/FTO 电池的 PCE 只有 $2.95 \%$; $\mathrm{TiC} / \mathrm{C}-\mathrm{Pt} / \mathrm{FTO}$ 对电极(7.21\%)由于 $\mathrm{TiC}$ 晶粒表 面分布的 Pt NPs 和 TiC 之间强烈的相互作用, 有着 与 $\mathrm{Pt}$ 对电极 $(7.54 \%) \mathrm{DSSC}$ 相媲美的性能。

\section{3 理论计算}

学者普遍认为催化剂的活性很大程度上取决于 其电子结构, 深入了解电催化过程有利于对 $\mathrm{TMCs}$ 对电极的理性笁选。基于密度泛函理论的第一性原 理(DFT)是目前研究材料电子结构的一种有效方法。 通过该量子化学计算分析可以从微观结构上研究对 电极材料的催化性质，阐明其催化机理。

Hou 等 ${ }^{[61]}$ 通过第一性原理量子化学计算, 研究 了电催化过程, 预测了潜在的对电极材料的催化活 性。并在理论预测的基础上, 实验验证了 $\alpha-\mathrm{Fe}_{2} \mathrm{O}_{3}$ 作为一种新的电极催化剂, 具有取代 Pt 电极的高电 催化活性(图 10)。另外, DFT 计算电子态密度(DOS)

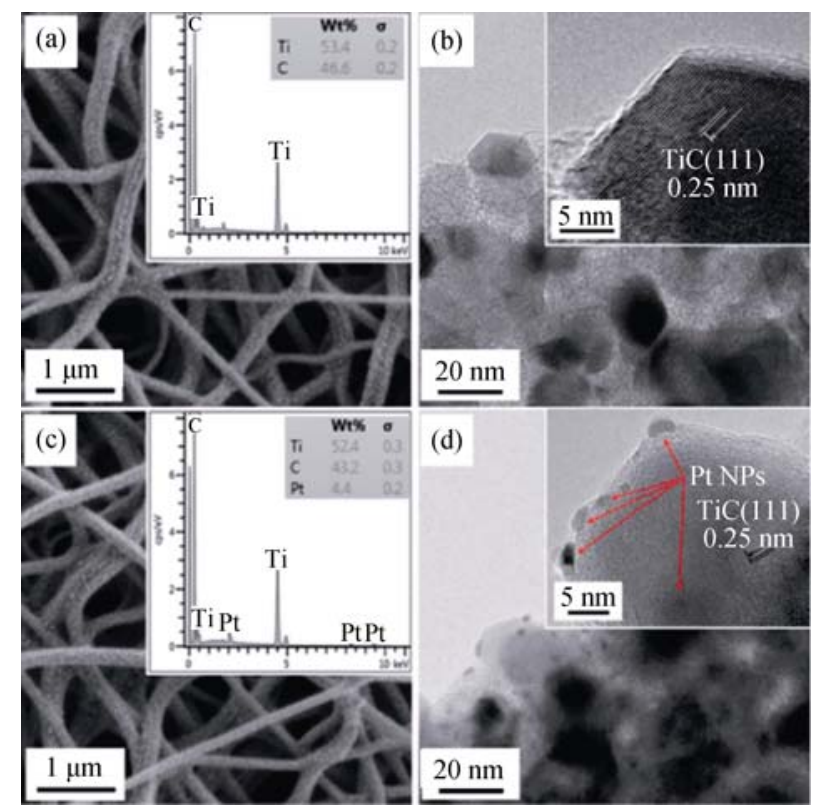

图 9 (a) TiC-C 纳米丝的 SEM 照片 (a 中内嵌图为 EDS 能谱 图), (b) TEM 照片 (b 中内嵌图为高倍 TEM 照片); (c) TiC/C-Pt 纳米材料的 SEM 照片 (c 中内嵌图为 EDS 能谱), 和(d) TEM 照片 (d 中内嵌图为高倍 TEM 照片) ${ }^{[60]}$

Fig. 9 (a) SEM image with EDS spectrum (inset); (b) TEM image with high magnification TEM image (inset) acquired from electrospun TiC/C nano-felt; (c) SEM image with EDS spectrum (inset), and (d) TEM image with high magnifycation TEM image (inset) acquired from electrospun $\mathrm{TiC} / \mathrm{C}$ nano-felt after surface-decoration with $\mathrm{Pt} \mathrm{NPs}^{[60]}$

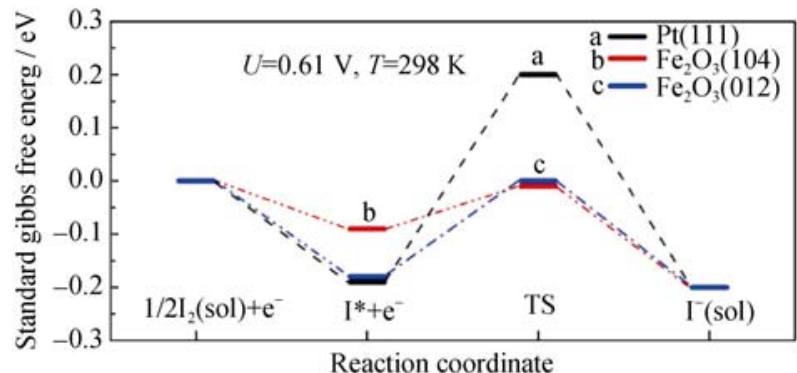

图 10 在 $U=0.61 \mathrm{~V}$ (vs SHE), 由第一性原理计算出的对电极 $\mathrm{Pt}(111) 、 \mathrm{Fe}_{2} \mathrm{O}_{3}(104)$ 和 $\mathrm{Fe}_{2} \mathrm{O}_{3}(012)$ 催化反应的能量图 ${ }^{[61]}$

Fig. 10 Energy profiles of the whole CE reaction on $\mathrm{Pt}(111)$, $\mathrm{Fe}_{2} \mathrm{O}_{3}(104)$ and $\mathrm{Fe}_{2} \mathrm{O}_{3}(012)$, respectively, which were calculated at $U=0.61 \mathrm{~V}(v s \mathrm{SHE})^{[61]}$

不仅可以确定 TMCs 表面的金属离子是否可以作为 催化反应位点(图 11), 还能验证 TMCs 的轨道杂化 能否为电子转移提供通道 ${ }^{[21]}$ 。此外, Car-Parrinello 分子动力学(CPMD)计算可以表征催化反应时催化 剂表面原子的距离变化, 评估电解质和催化剂的表 面作用 ${ }^{[62]}$, 另一方面也为不同电解质的选择使用提 拱了理论依据。

除此之外，第一性原理计算还可以解释 $\mathrm{TMCs}$ 催化性能强弱的原因。例如为什么碳化物比氧化物 催化活性高, 而一些氧化物又比氮化物催化能力 强 ${ }^{[23]}$ 。另外，在不同 TMCs 中添加碳材料(MC), 可 以为电子转移提供更多的通道, 但其催化性能的改 变则由 DFT 计算论证：表面原子的成键类型以及表 面能将影响 $\mathrm{I}_{3}{ }^{-}$的吸附, 从而影响催化过程 ${ }^{[35]}$ 。

总之, 通过理论计算, 不仅可以洞察 $\mathrm{CE}$ 材料固 有的催化性能，还有助于预测篎选高效的新化合物 作为 $\mathrm{CE}$ 材料 ${ }^{[31]}$ 。需要注意的是, 材料的粒度、晶 体结构、表面面积、厚度、孔隙率、密合性和形态 也显著影响催化剂的活性和 $\mathrm{CE}$ 的电化学特性。

\section{4 匹配性}

众所周知, DSSC 的性能依赖于电池各组件的综 合表现。截止目前, TMCs 对电极电池 PCE 最高为 $9.40 \%{ }^{[49]}$, 以 $\mathrm{Co}_{0.85} \mathrm{Se} / \mathrm{FTO}$ 为对电极, 使用 $\mathrm{I}^{\mathrm{I}} / \mathrm{I}_{3}{ }^{-}$电解质 和 N719 染料。可以说大多数的 TMCs 对电极都与传 统的 $\mathrm{I}^{-} / \mathrm{I}_{3}{ }^{-}$电解质匹配良好, 显示出接近 Pt 对电极的电 池 $\mathrm{PCE}$ 。然而 $\mathrm{I}^{-} / \mathrm{I}_{3}{ }^{-}$电解质虽然有着理想电解质的一些 优点：对光阳极没有明显溶解、溶液粘度低利于扩散 传输，复合反应缓慢等。但也有着易于腐蚀金属电 极、对可见光存在吸收、中间产物 $\mathrm{I}_{2}$ 易挥发等缺点，最 终影响 DSSC 的使用寿命和大规模的工业生产应 用。因此, 近年来不断有学者致力于开发非碘氧化还 

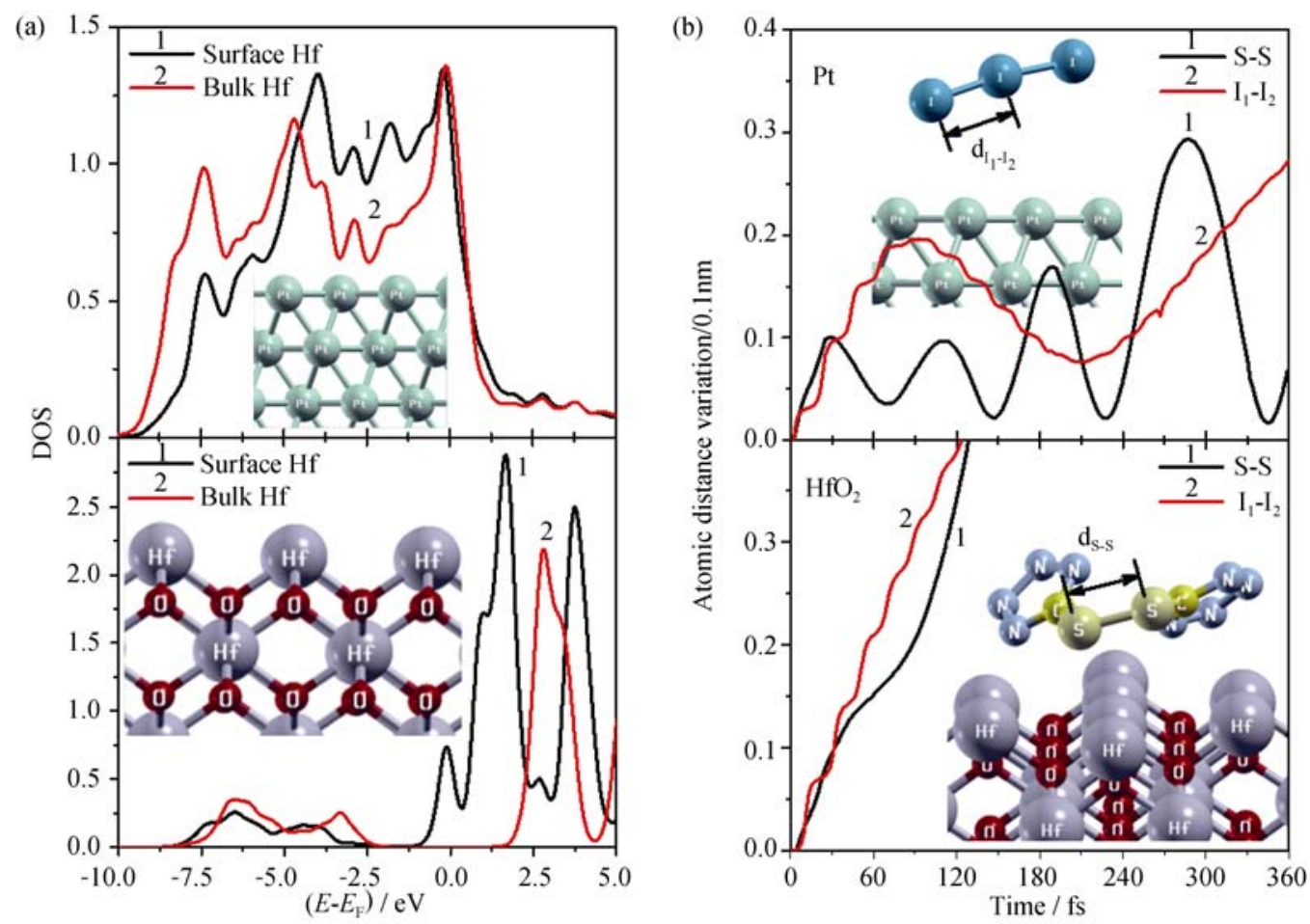

图 11 (a)d 轨道上 $\mathrm{Pt}$ 和 $\mathrm{Hf}$ 原子的 DOS 图, (b)不同时间下 $\mathrm{Pt}$ 和 $\mathrm{HfO}_{2}$ 原子表面上 $\mathrm{I}$ 与 $\mathrm{I}_{3}, \mathrm{~S}$ 原子在 $\mathrm{T}_{2}$ 染料环境的距离变化图 ${ }^{[21]}$

Fig. 11 (a) The projected density of state (DOS) on the d orbital of Pt and Hf atoms, and (b) the atomic distance variation with respect to time for I atoms in $\mathrm{I}_{3}$ and $\mathrm{S}$ atoms in $\mathrm{T}_{2}$ on $\mathrm{Pt}$ and $\mathrm{HfO}_{2}{ }^{[21]}$

原对电解质。例如 $\mathrm{Co}^{2+} / \mathrm{Co}^{3+}$ 电解质对可见光几乎无 吸收, 不腐蚀金属电极; 电对自身电势高, 降低了 能量损失, 使得开路电压提高。而 $\mathrm{T}^{-} / \mathrm{T}_{2}$ 电解质绿色 环保, 高效。在 $\mathrm{T}^{-} / \mathrm{T}_{2}$ 或者 $\mathrm{Co}^{2+} / \mathrm{Co}^{3+}$ 电解质环境中,
TMCs 对电极表现出超越 Pt 对电极的电池性能 ${ }^{[63-64]}$ (表 1)。究其原因是 $\mathrm{Co}^{2+} / \mathrm{Co}^{3+}$ 电解质体积大, 使得电 荷在传统的 Pt 对电极上转移困难, 而 TMCs 电极多 样的结构有利于电荷转移。

表 1 使用不同衬底、染料、电解质以及对电极催化剂组装的染料敏化太阳能电池光电性能

Table 1 Photovoltaic parameters of dye-sensitized solar cells with different substrates, redox couples, dyes, and CE catalysts

\begin{tabular}{|c|c|c|c|c|c|c|c|c|}
\hline CE catalysts & Substrate & $\begin{array}{c}\text { Redox } \\
\text { couples }\end{array}$ & Dye & $\begin{array}{c}J_{\mathrm{sc}} / \\
\left(\mathrm{mA} \cdot \mathrm{cm}^{-2}\right)\end{array}$ & $V_{\mathrm{oc}} / \mathrm{V}$ & $F F$ & $\mathrm{PCE} / \%$ & Ref \\
\hline $\mathrm{C}_{0.85} \mathrm{Se}$ & FTO & $\mathrm{I}^{-} / \mathrm{I}_{3}^{-}$ & N719 & 16.98 & 0.738 & 0.75 & 9.40 & [49] \\
\hline $\mathrm{TiC}$ & FTO & $\mathrm{Co}^{2+} / \mathrm{Co}^{3+}$ & N719 & 9.77 & 0.640 & 0.66 & 4.13 & {$[63]$} \\
\hline Carbon $/ \mathrm{SnO}_{2} / \mathrm{TiO}_{2}$ & FTO & $\mathrm{I}^{-} / \mathrm{I}_{3}^{-}$ & $\mathrm{N} 3$ & 12.98 & 0.740 & 0.64 & 6.15 & {$[66]$} \\
\hline $\mathrm{NiO}-\mathrm{Pt}$ & FTO & $\mathrm{I}^{-} / \mathrm{I}_{3}^{-}$ & Ru535 & 0.30 & 0.530 & 0.63 & 2.80 & {$[71]$} \\
\hline $\mathrm{Co}_{9} \mathrm{~S}_{8}$ & Mo & $\mathrm{I}^{-} / \mathrm{I}_{3}^{-}$ & N719 & 13.98 & 0.720 & 0.69 & 6.91 & {$[32]$} \\
\hline $\mathrm{TiN}$ & $\mathrm{Ti}$ & $\mathrm{I}^{-} / \mathrm{I}_{3}^{-}$ & N719 & 15.78 & 0.760 & 0.64 & 7.73 & {$[67]$} \\
\hline TiN/PEDOT-PSS & $\mathrm{Ti}$ & $\mathrm{I}^{-} / \mathrm{I}_{3}^{-}$ & CYC-B1 & 14.20 & 0.68 & 0.69 & 6.67 & {$[69]$} \\
\hline $\mathrm{NiS}$ & $\mathrm{Ni}$ & $\mathrm{I}^{-} / \mathrm{I}_{3}^{-}$ & N719 & 16.26 & 0.800 & 0.66 & 8.55 & {$[45]$} \\
\hline $\mathrm{TiC}$ & $\mathrm{BG} / \mathrm{CC}$ & $\mathrm{I}^{-} / \mathrm{I}_{3}^{-}$ & N719 & 12.98 & 0.790 & 0.56 & 5.71 & {$[68]$} \\
\hline $\mathrm{TiC}$ & $\mathrm{PI} / \mathrm{CC}$ & $\mathrm{I}^{-} / \mathrm{I}_{3}^{-}$ & N719 & 12.32 & 0.770 & 0.41 & 3.90 & {$[68]$} \\
\hline $\mathrm{FeS}_{2}$ & ITO/PEN & $\mathrm{I}^{-} / \mathrm{I}_{3}^{-}$ & N719 & 15.14 & 0.710 & 0.68 & 7.31 & {$[31]$} \\
\hline $\mathrm{CoS}$ & ITO/PEN & $\mathrm{I}^{-} / \mathrm{I}_{3}^{-}$ & Z907 & 11.91 & 0.750 & 0.73 & 6.50 & [41] \\
\hline $\mathrm{TiO}_{2}-\mathrm{C}$ & FTO & $\mathrm{I}^{-} / \mathrm{I}_{3}^{-}$ & Z907 & 12.53 & 0.700 & 0.57 & 5.50 & [70] \\
\hline $\operatorname{CoS}$ & ITO/PEN & $\mathrm{T}_{2} / \mathrm{T}^{-}$ & Z907 & 14.60 & 0.643 & 0.49 & 4.60 & {$[65]$} \\
\hline TiN-C & FTO & $\mathrm{T}_{2} / \mathrm{T}^{-}$ & N719 & 14.36 & 0.697 & 0.67 & 6.71 & {$[22]$} \\
\hline $\mathrm{Ta}_{3} \mathrm{~N}_{5} /$ Graphene & FTO & $\mathrm{Co}^{2+} / \mathrm{Co}^{3+}$ & FNE29 & 13.53 & 0.837 & 0.69 & 7.85 & {$[64]$} \\
\hline
\end{tabular}

$V_{\text {oc }}$ : open-circuit voltage; $J_{\mathrm{sc}}$ : short-circuit current density; FF: fill factor; PCE: power conversion efficiency; BG: bare glass; PI: polyimide CC: conductive carbon 
金属络合物电解质虽然有着优异的电化学性能, 但也存在着复合反应快, 体积大不易扩散转移, 稳 定性差等缺点。离子液体电解质也同样面临着类似 的情况。有机硫电解质呈碱性以及流动性差等原因 只能匹配量子点敏化太阳能电池。由此, 在寻找替 代贵金属 Pt 的催化材料时可以结合 TMCs 种类繁多, 结构多样, 制备方式多种多样的优势, 探索出利于 电子转移, 同时能发挥新型电解质优势的新型 $\mathrm{TMCs}$ 对电极。

另外, 复合对电极催化剂在不同的染料以及电 解质环境中, 明显较单一成分的对电极性能优越, 意味着多组分催化剂更容易与电池其它组分匹配, 提高电池性能 $[22,64,66,69]$ 。

除此之外, 电池使用的染料 ${ }^{[65-66]}$ 以及电极祄 底 ${ }^{[32,67-68]}$ 也会与其它部件相互作用, 最终影响 DSSC 的 性能(表 1)。也有学者尝试使用新型染料 ${ }^{[41.69-71]}$, 比 如匹配合适的染料可以有效抑制电解质中的复合反 应。因此新型染料必须匹配新型光阳极、电解质和 对电极才能达到良好的电池性能 ${ }^{[64]}$ 。

电极中广泛使用的 FTO 导电玻璃衬底, 虽然透 光性强, 但存在易碎, 质量大, 不易加工等缺点, 制约着 DSSC 的实际应用。而各种柔性祄底对电极 的成功制备, 扩大了 DSSC 各部件的选择范围, 有 望解决 DSSC 高成本以及稳定性差等问题, 还可以 应用于工业大面积 DSSC 的生产 ${ }^{[41,67-68]}$ 。

为了促进 DSSC 的商业应用, 必须改善传统的 TMCs 对电极材料的设计和制备策略，提高电池的 各组件(染料、电解质、光阳极和对电极)的匹配度。

\section{5 总结和展望}

具有类 $\mathrm{Pt}$ 催化性能的过渡金属化合物制备方 式简单多样, 不少过渡金属化合物还可以应用于柔 性祄底, 以及大面积 DSSC 的生产。但是过渡金属 化合物优异的催化活性的作用机理尚不清楚, 利用 理论计算深入研究过渡金属化合物在 DCCS 应用上 的催化性能机理, 以对其实现可控制备是今后研究 的重点。结合实际应用, 研究开发绿色环保、价格 低廉、性能优异的可替代 Pt 对电极的新型过渡金属 化合物材料, 有可能满足不同类型 DSSC 器件(如刚 性、柔性、液态、固态、单基板、叠层及量子点等) 日益发展的需求。此外, 新型过渡金属化合物材料 还可能解决燃料电池、制氢、储能、污染控制等新 型能源领域中贵金属 Pt 催化材料面临的压力和挑 战, 以促进类 Pt 清洁能源催化材料的产业化进程。

\section{参考文献:}

[1] O'REGAN B, GRÄTZEL M. A low-cost, high-efficiency solar cell based on dye-sensitized colloidal $\mathrm{TiO}_{2}$ films. Natrue, 1991, 353(6346): 737-740.

[2] GRÄTZEL M. Photoelectrochemical cells. Nature, 2001, 414(6861): 338-344.

[3] VOUGIOUKALAKIS G C, PHILIPPOPOUlOS A I, STERGIOPOULOS T, et al. Contributions to the development of ruthenium-based sensitizers for dye-sensitized solar cells. Coordination Chemistry Reviews, 2011, 255(21): 2602-2621.

[4] Yella A, LEE H W, TSAO H N, et al. Porphyrin-sensitized solar cells with cobalt (II/III)-based redox electrolyte exceed 12 percent efficiency. Science, 2011, 334(6056): 629-634.

[5] HAUCH A, GEORG A. Diffusion in the electrolyte and charge-transfer reaction at the platinum electrode in dye-sensitized solar cells. Electrochimica Acta, 2001, 46(22): 3457-3466.

[6] LEE Y L, CHEN C L, CHONG L W, et al. A platinum counter electrode with high electrochemical activity and high transparency for dye-sensitized solar cells. Electrochemistry Communications, 2010, 12(11): 1662-1665.

[7] CHEN L, TAN W, ZHANG J, et al. Fabrication of high performance Pt counter electrodes on conductive plastic substrate for flexible dye-sensitized solar cells. Electrochimica Acta, 2010, 55(11): 3721-3726.

[8] KAY A, GRÄTZEL M. Low cost photovoltaic modules based on dye sensitized nanocrystalline titanium dioxide and carbon powder. Solar Energy Materials and Solar Cells, 1996, 44(1): 99-117.

[9] LEE W J, RAMASAMY E, LEE D Y, et al. Efficient dye-sensitized solar cells with catalytic multiwall carbon nanotube counter electrodes. ACS Applied Materials \& Interfaces, 2009, 1(6): $1145-1149$.

[10] RAMASAMY E, CHUN J, LEE J. Soft-template synthesized ordered mesoporous carbon counter electrodes for dye-sensitized solar cells. Carbon, 2010, 48(15): 4563-4565.

[11] NAM J G, PARK Y J, KIM B S, et al. Enhancement of the efficiency of dye-sensitized solar cell by utilizing carbon nanotube counter electrode. Scripta Materialia, 2010, 62(3): 148-150.

[12] LEE K M, CHEN P Y, HSU C Y, et al. A high-performance counter electrode based on poly (3, 4-alkylenedioxythiophene) for dye-sensitized solar cells. Journal of Power Sources, 2009, 188(1): 313-318.

[13] ZHANG J, HREID T, LI X, et al. Nanostructured polyaniline counter electrode for dye-sensitised solar cells: fabrication and investigation of its electrochemical formation mechanism. Electrochimica Acta, 2010, 55(11): 3664-3668.

[14] AMEEN S, AKHTAR M S, KIM Y S, et al. Sulfamic acid-doped polyaniline nanofibers thin film-based counter electrode: application in dye-sensitized solar cells. The Journal of Physical Chemistry C, 2010, 114(10): 4760-4764.

[15] MAKRIS T, DRACOPOULOS V, STERGIOPOULOS T, et al. A quasi solid-state dye-sensitized solar cell made of polypyrrole counter electrodes. Electrochimica Acta, 2011, 56(5): 
2004-2008.

[16] LEVY R B, BOUDART M. Platinum-like behavior of tungsten carbide in surface catalysis. Science, 1973, 181(4099): 547-549.

[17] FURIMSKY E. Metal carbides and nitrides as potential catalysts for hydroprocessing. Applied Catalysis A: General, 2003, 240(1): $1-28$.

[18] WU M, LIN X, WANG Y, et al. Economical Pt-free catalysts for counter electrodes of dye-sensitized solar cells. Journal of the American Chemical Society, 2012, 134(7): 3419-3428.

[19] WU M, LIN X, WANG L, et al. In situ synthesized economical tungsten dioxide imbedded in mesoporous carbon for dye-sensitized solar cells as counter electrode catalyst. The Journal of Physical Chemistry C, 2011, 115(45): 22598-22602.

[20] YUN S, ZHANG H, PU H, et al. Metal oxide/carbide/carbon nanocomposites: in situ synthesis, characterization, calculation, and their application as an efficient counter electrode catalyst for dye-sensitized solar cells. Advanced Energy Materials, 2013, 3(11): 1407-1412.

[21] YUN S, PU H, CHEN J, et al. Enhanced performance of supported $\mathrm{HfO}_{2}$ counter electrodes for redox couples used in dye-sensitized solar cells. ChemSusChem, 2014, 7(2): 442-450.

[22] RAMASAMY E, JO C, ANTHONYSAMY A, et al. Soft-template simple synthesis of ordered mesoporous titanium nitride-carbon nanocomposite for high performance dye-sensitized solar cell counter electrodes. Chemistry of Materials, 2012, 24(9): 1575-1582.

[23] YUN S, HAGFELdT A, MA T. Pt-free counter electrode for dye-sensitized solar cells with high efficiency. Advanced Materials, 2014, 26(36): 6210-6237.

[24] GIORDANO C, ERPEN C, YAO W, et al. Metal nitride and metal carbide nanoparticles by a soft urea pathway. Chemistry of Materials, 2009, 21(21): 5136-5144.

[25] LIN X, WU M, WANG Y, et al. Novel counter electrode catalysts of niobium oxides supersede $\mathrm{Pt}$ for dye-sensitized solar cells. Chemical Communications, 2011, 47(41): 11489-11491.

[26] WU M, GUO H, LIN Y N, et al. Synthesis of highly effective vanadium nitride $(\mathrm{VN})$ peas as a counter electrode catalyst in dye-sensitized solar cells. The Journal of Physical Chemistry C, 2014, 118(24): 12625-12631.

[27] YUN S, WU M, WANG Y, et al. Pt-like behavior of high-performance counter electrodes prepared from binary tantalum compounds showing high electrocatalytic activity for dye-sensitized solar cells. ChemSusChem, 2013, 6(3): 411-416.

[28] YUN S, WANG L, GUO W, et al. Non-Pt counter electrode catalysts using tantalum oxide for low-cost dye-sensitized solar cells. Electrochemistry Communications, 2012, 24(10): 69-73.

[29] YUN S, ZHOU H, WANG L, et al. Economical hafnium oxygen nitride binary/ternary nanocomposite counter electrode catalysts for high-efficiency dye-sensitized solar cells. J. Mater. Chem. A, 2013, 1(4): 1341-1348.

[30] WU M, ZHANG Q, XIAO J, et al. Two flexible counter electrodes based on molybdenum and tungsten nitrides for dye-sensitized solar cells. Journal of Materials Chemistry, 2011, 21(29): $1761-1766$.
[31] WANG Y C, WANG D Y, JIANG Y T, et al. $\mathrm{FeS}_{2}$ nanocrystal ink as a catalytic electrode for dye-sensitized solar cells. Angew. Chem. Int. Ed. Engl., 2013, 52(26): 6694-6698.

[32] CHANG S H, LU M D, TUNG Y L, et al. Gram-scale synthesis of catalytic $\mathrm{Co}_{9} \mathrm{~S}_{8}$ nanocrystal ink as a cathode material for spray-deposited, large-area dye-sensitized solar cells. ACS Nano, 2013, 7(10): 9443-9451.

[33] BI H, ZHAO W, SUN S, et al. Graphene films decorated with metal sulfide nanoparticles for use as counter electrodes of dyesensitized solar cells. Carbon, 2013, 61(11): 116-123.

[34] XIA J, YUAN C, YANAGIDA S. Novel counter electrode $\mathrm{V}_{2} \mathrm{O}_{5} / \mathrm{Al}$ for solid dye-sensitized solar cells. ACS Applied Materials \& Interfaces, 2010, 2(7): 2136-2139.

[35] DAS S, SUDHAGAR P, NAGARAJAN S, et al. Synthesis of graphene$\mathrm{CoS}$ electro-catalytic electrodes for dye sensitized solar cells. Carbon, 2012, 50(13): 4815-4821.

[36] DAS S, SUDHAGAR P, VERMA V, et al. Amplifying chargetransfer characteristics of graphene for triiodide reduction in dye-sensitized solar cells. Advanced Functional Materials, 2011, 21(19): 3729-3736.

[37] TAI S Y, LIU C J, CHOU S W, et al. Few-layer $\mathrm{MoS}_{2}$ nanosheets coated onto multi-walled carbon nanotubes as a low-cost and highly electrocatalytic counter electrode for dye-sensitized solar cells. Journal of Materials Chemistry, 2012, 22(47): 24753-24759.

[38] LIN J Y, LIAO J H, HUNG T Y. A composite counter electrode of CoS/MWCNT with high electrocatalytic activity for dye-sensitized solar cells. Electrochemistry Communications, 2011, 13(9): 977-980.

[39] XIAO Y, WU J, LIN J Y, et al. Pulse electrodeposition of CoS on MWCNT/Ti as a high performance counter electrode for a Pt-free dye-sensitized solar cell. J. Mater. Chem. A, 2013, 1(4): 1289-1295.

[40] XIAO Y, HAN G, CHANG Y, et al. Cobalt sulfide counter electrodes enhanced by a hydro-thermal treatment for use in platinum-free dye-sensitized solar cells. Materials Research Bulletin, 2015, 68: 9-15.

[41] WANG M, ANGHEL A M, MARSAN B, et al. CoS supersedes Pt as efficient electrocatalyst for triiodide reduction in dye-sensitized solar cells. Journal of the American Chemical Society, 2009, 131(44): 15976-15977.

[42] WU M S, CHUNG C J, CENG Z Z. Cyclic voltammetric deposition of discrete nickel phosphide clusters with mesoporous nanoparticles on fluorine-doped tin oxide glass as a counter electrode for dye-sensitized solar cells. RSC Adv., 2015, 5(6): 4561-4567.

[43] ZHANG Z, PANG S, XU H, et al. Electrodeposition of nanostructured cobalt selenide films towards high performance counter electrodes in dye-sensitized solar cells. RSC Advances, 2013, 3(37): 16528-16534.

[44] HU Z, XIA K, ZHANG J, et al. In situ growth of novel laminarshaped $\mathrm{Co}_{3} \mathrm{~S}_{4}$ as an efficient counter electrode for dye-sensitized solar cells. RSC Adv., 2014, 4(81): 42917-42923.

[45] KE W, FANG G, TAO H, et al. In situ synthesis of NiS nanowall networks on $\mathrm{Ni}$ foam as a TCO-free counter electrode for 
dye-sensitized solar cells. ACS Appl. Mater. Interfaces, 2014, 6(8): 5525-5530.

[46] LIAO Y, PAN K, PAN Q, et al. In situ synthesis of a NiS/ $/ \mathrm{Ni}_{3} \mathrm{~S}_{2}$ nanorod composite array on Ni foil as a FTO-free counter electrode for dye-sensitized solar cells. Nanoscale, 2015, 7(5): $1623-1626$

[47] ZHAO W, LIN T, SUN S, et al. Oriented single-crystalline nickel sulfide nanorod arrays: "two-in-one" counter electrodes for dye-sensitized solar cells. Journal of Materials Chemistry A, 2013, 1(2): 194-198.

[48] KIM H J, KIM C W, PUNNOOSE D, et al. Nickel doped cobalt sulfide as a high performance counter electrode for dye-sensitized solar cells. Applied Surface Science, 2015, 328: 78-85.

[49] GONG F, WANG H, XU X, et al. In situ growth of Co(0.85)Se and $\mathrm{Ni}(0.85) \mathrm{Se}$ on conductive substrates as high-performance counter electrodes for dye-sensitized solar cells. Journal of the American Chemical Society, 2012, 134(26): 10953-10958.

[50] GONG F, XU X, LI Z, et al. $\mathrm{NiSe}_{2}$ as an efficient electrocatalyst for a Pt-free counter electrode of dye-sensitized solar cells. Chemical Communications, 2013, 49(14): 1437-1439.

[51] CHI W S, HAN J W, YANG S, et al. Employing electrostatic self-assembly of tailored nickel sulfide nanoparticles for quasi-solid-state dye-sensitized solar cells with Pt-free counter electrodes. Chemical Communications, 2012, 48(76): 9501-9503.

[52] SONG J, LI G R, XIONG F Y, et al. Synergistic effect of molybdenum nitride and carbon nanotubes on electrocatalysis for dye-sensitized solar cells. Journal of Materials Chemistry, 2012, 22(38): 20580-20585.

[53] YUE G, WU J, LIN J Y, et al. A counter electrode of multi-wall carbon nanotubes decorated with tungsten sulfide used in dye-sensitized solar cells. Carbon, 2013, 55(1): 1-9.

[54] GUO J, SHI Y, ZHU C, et al. Cost-effective and morphologycontrollable niobium diselenides for highly efficient counter electrodes of dye-sensitized solar cells. Journal of Materials Chemistry A, 2013, 1(38): 11874-11879.

[55] JANG J S, HAM D J, RAMASAMY E, et al. Platinum-free tungsten carbides as an efficient counter electrode for dye sensitized solar cells. Chemical Communications, 2010, 46(45): 8600-8602.

[56] ZHOU H, SHI Y, DONG Q, et al. Interlaced $\mathrm{W}_{18} \mathrm{O}_{49}$ nanofibers as a superior catalyst for the counter electrode of highly efficient dye-sensitized solar cells. Journal of Materials Chemistry A, 2014, 2 (12): 4347-4354.

[57] ZHOU H, SHI Y, WANG L, et al. Notable catalytic activity of oxygen-vacancy-rich $\mathrm{WO}(2.72)$ nanorod bundles as counter electrodes for dye-sensitized solar cells. Chemical Communications, 2013, 49(69): 7626-7628.
[58] DOU Y Y, LI G R, SONG J, et al. Nickel phosphide-embedded graphene as counter electrode for dye-sensitized solar cells. Physical Chemistry Chemical Physics: PCCP, 2012, 14(4): 1339-1342.

[59] GUO J, SHI Y, CHU Y, et al. Highly efficient telluride electrocatalysts for use as Pt-free counter electrodes in dye-sensitized solar cells. Chemical Communications, 2013, 49(86): 10157-10159.

[60] ZHAO Y, THAPA A, FENG Q, et al. Electrospun TiC/C nano-felt surface-decorated with $\mathrm{Pt}$ nanoparticles as highly efficient and cost-effective counter electrode for dye-sensitized solar cells. Nanoscale, 2013, 5(23): 11742-11747.

[61] HOU Y, WANG D, YANG X, et al. Rational screening low-cost counter electrodes for dye-sensitized solar cells. Nature Communications, 2013, 4(3): 1583-1591.

[62] YUN S, HAGFELDT A, MA T. Superior catalytic activity of sub$5 \mu \mathrm{m}$-thick $\mathrm{Pt} / \mathrm{SiC}$ films as counter electrodes for dye-sensitized solar cells. Chem. Cat. Chem., 2014, 6(6): 1584-1588.

[63] WANG L, DIAU E W, WU M, et al. Highly efficient catalysts for $\mathrm{Co}(\mathrm{II} / \mathrm{III})$ redox couples in dye-sensitized solar cells. Chemical Communications, 2012, 48(20): 2600-2602.

[64] WANG H, FENG Q, GONG F, et al. In situ growth of oriented polyaniline nanowires array for efficient cathode of $\mathrm{Co}(\mathrm{iii}) / \mathrm{Co}(\mathrm{ii})$ mediated dye-sensitized solar cell. J. Mater. Chem. A, 2013, 1(1): 97-104.

[65] BURSCHKA J, BRAULT V, AHMAD S, et al. Influence of the counter electrode on the photovoltaic performance of dye-sensitized solar cells using a disulfide/thiolate redox electrolyte. Energy \& Environmental Science, 2012, 5(3): 6089-6097.

[66] SUN W, SUN X, PENG T, et al. A low cost mesoporous carbon $/ \mathrm{SnO}_{2} / \mathrm{TiO}_{2}$ nanocomposite counter electrode for dye-sensitized solar cells. Journal of Power Sources, 2012, 201(1): 402-407.

[67] JIANG Q W, LI G R, GAO X P. Highly ordered TiN nanotube arrays as counter electrodes for dye-sensitized solar cells. Chemical Communications, 2009, 45(44): 6720-6722.

[68] WANG Y, WU M, LIN X, et al. Several highly efficient catalysts for Pt-free and FTO-free counter electrodes of dye-sensitized solar cells. Journal of Materials Chemistry, 2012, 22(9): 4009-4014.

[69] YEH M H, LIN L Y, LEE C P, et al. A composite catalytic film of PEDOT:PSS/TiN-NPs on a flexible counter-electrode substrate for a dye-sensitized solar cell. Journal of Materials Chemistry, 2011, 21(47): 19021-19029.

[70] JOSHI P, XIE Y, ROPP M, et al. Dye-sensitized solar cells based on low cost nanoscale carbon $/ \mathrm{TiO}_{2}$ composite counter electrode. Energy \& Environmental Science, 2009, 2(4): 426-429.

[71] KIM S, PARK K, YUM J, et al. Pt-NiO nanophase electrodes for dye-sensitized solar cells. Solar Energy Materials and Solar Cells, 2006, 90(3): 283-290. 